\title{
PENERAPAN MODEL PEMBELAJARAN KOOPERATIF TIPE ROTATING TRIO EXCHANGE (RTE) UNTUK MENGURANGI KECEMASAN MATEMATIKA SISWA
}

\author{
Hazuar $^{1}$, Zainal Abidin ${ }^{2}$, Cut Intan Salasiyah ${ }^{3}$ \\ 1,2,3 Universitas Islam Negeri Ar-Raniry, Jalan Syekh Abdur Rauf, Banda Aceh 23111, Indonesia \\ Email: hazuar09@gmail.com \\ Email: zainalabidin@ar-raniry.ac.id \\ Email: cutintan@ar-raniry.ac.id
}

\begin{abstract}
Dalam mempelajari matematika siswa sering kali merasakan kegelisahan, kekhawatiran, keprihatinan dan rasa takut. Sehingga dari perasaan tersebut muncul rasa cemas siswa dalam pelajaran matematika. Kecemasan dalam pembelajaran matematika adalah salah satu masalah yang mempengaruhi pembelajaran sehingga harus diminimalkan atau bahkan dihilangkan. Salah satu alternatif yang dapat mengurangi kecemasan siswa terhadap pembelajaran matematika adalah dengan penerapan model pembelajaran Kooperatif tipe Rotating Trio Exchange (RTE). Tujuan dari penelitian ini adalah untuk mengetahui apakah dengan penerapan model pembelajaran RTE dapat mengurangi tingkat kecemasan matematika. Pada penelitian ini, peneliti menggunakan pendekatan kuantitatif. Desain penelitian ini kuasi eksperimen kelompok kontrol tak setara (non equivalent control group desain). Subjek penelitian ini adalah siswa kelas VII-4 yang terdiri 31 orang dan kelas VII-2 yang terdiri dari 29 orang. Data dikumpulkan melalui pengukuran angket kecemasan matematika dan observasi. Berdasarkan hasil pengolahan data diperoleh bahwa tingkat kecemasan matematika siswa sebelum dan setelah penerapan model pembelajaran Kooperatif tipe RTE mengalami penurunan. Sebelum penerapan model RTE jumlah siswa yang mengalami sangat cemas 2 orang dan setelah penerapan siswa yang mengalami sangat cemas tidak ada lagi. Siswa yang mengalami cemas sebelum penerapan 15 orang dan setelah penerapan menjadi 4 orang. Siswa yang mengalami kecemasan sedang sebelum penerapan 8 0rang setelah penerapan menjadi 16 orang. Siswa yang tidak cemas sebelum penerapan 6 orang dan setelah penerapan menjadi 11 orang. Pesentase kecemasan siswa secara keleuruha, Sebelum penerapan model RTE tingkat kecemasan matematika siswa sebanyak $80,65 \%$ dan setelah pembelajaran menggunakan model RTE tingkat kecemasan matematika siswa menurun menjadi $64,51 \%$. Artinya pembelajaran dengan model RTE dapat mengurangi tingkat kecemasan matematika dari $80,65 \%$ menjadi $64,51 \%$. Berarti kecemasan matematika siswa berkurang sebanyak $16,14 \%$. Dari hasil penelitian digunakanlah statistik uji-t pihak kiri dengan taraf signifikan 5\%. Berdasarkan kriteria pengujian adalah tolak $H_{1}$ jika $t_{\text {hitung }} \leq t_{\text {tabel }}$, telah didapat bahwa $t_{\text {hitung }}=0,283$ dan $t_{\text {tabel }}=1,68$. Ini artinya $t_{\text {hitung }}<t_{\text {tabel }}$ yaitu $0,283<1,68$ sehingga $H_{\square}$ ditolak, maka $H_{u}$ diterima. Sehingga, dapat disimpulkan bahwa tingkat kecemasan matematika siswa melalui penerapan model RTE lebih rendah dari tingkat kecemasan matematika siswa melalui pembelajaran konvensional.
\end{abstract}

Kata Kunci: Model Pembelajaran Kooperatif tipe RTE, Kecemasan Matematika

\section{PENDAHULUAN}

Pendidikan merupakan salah satu upaya yang dapat ditempuh untuk menyiapkan sumber daya manusia yang berkualitas yang hendak dicapai. Pendidikan menjadi salah satu sektor penting untuk dikembangkan sehingga menghasilkan sumber daya manusia yang berkualitas, kompetitif dan memiliki daya saing yang tinggi. Pembenahan kualitas pendidikan haruslah menjadi pilihan utama bagi pemerintah untuk menjadikan bangsa yang mampu bersaing bahkan mendominasi dan memenangkan persaingan tersebut. Diperlukan peningkatan dan pengembangan sikap kompetitif sumber daya manusia melalui pendidikan. 
Matematika mempunyai peran yang sangat besar dalam perkembangan Ilmu Pengetahuan dan Teknologi (IPTEK). Budiyono mengatakan "Matematika merupakan wahana untuk mempelajari ilmu pengetahuan dan ilmu pengetahuan tidak akan dapat berkembang tanpa Matematika. Matematika merupakan ilmu yang universal sreta mendasari perkembangan tekonologi modern, mempunyai peran penting dalam berbagai disiplin dan memajukan daya pikir manusia.

Akan tetapi yang menjadi permasalahan adalah pandangan yang berkembang selama ini menganggap keberhasilan belajar umumnya hanya dipengaruhi oleh tingkat intelegensi saja. Bahkan banyak yang beranggapan untuk menguasai matematika diperlukan tingkat intelegensi di atas rata-rata sebagai satu-satunya syarat mutlak. Masyarakat secara umum dan siswa pada khususnya menganggap matematika adalah mata pelajaran yang sulit dipelajari dan juga merupakan mata pelajaran yang menakutkan. Namun, beberapa penelitian akhir-akhir ini membuktikan bahwa prestasi belajar siswa tidak hanya ditentukan oleh intelegensi, tetapi juga di pengaruhi oleh kecemasan dan kreativitas siswa.

Dalam buku karangan Mulyo Abdurahman Kecemasan atau dalam Bahasa Inggrisnya "anxiety" berasal dari Bahasa Latin "angustus" yang berarti kaku, dan "ango, anci" yang berarti mencekik. Konsep kecemasan memegang peranan yang sangat mendasar dalam teori-teori tentang stress dan penyesuaian diri. Kecemasan merupakan manifestasi dari berbagai proses emosi yang bercampur baur yang dimiliki individu. Freud mendefinisikan kecemasan adalah suatu pengalaman perasaan yang menyakitkan yang ditimbulkan oleh ketegangan-ketegangan dalam alat-alat intern dari tubuh. Kecemasan merupakan emosi yang tidak menyenangkan, yang ditandai dengan istilah-istilah seperti "kekhawatiran", "keprihatinan", dan "rasa takut" yang kadang-kadang kita alami dalam tingkat yang berbeda-beda.

Kegelisahan atau kecemasan sering kali dialami oleh siswa. Mereka tidak senang dalam mengerjakan tugas-tugas dan merasa bahwa matematika itu sulit, menakutkan, dan tidak semua orang dapat mengerjakannya. Dari rasa takut tersebut memunculkan kecemasan ketika siswa belajar matematika atau disebut juga kecemasan matematika.

Kecemasan matematika ini berakibat pada pengendalian diri, dorongan untuk bertindak, ketekunan, semangat, dan motivasi belajar serta kecendrungan menghindari pembelajaran matematika yang berpengaruh pada prestasi belajar matematika siswa dan bahkan kecemasan matematika menjadi penyebab paling signifikan yang dapat menghalangi prestasi belajar matematika siswa.

Berdasarkan hasil observasi dan wawancara yang penulis lakukan pada tanggal 25 Juli 2016 dengan siswa MTsN Rukoh Banda Aceh, masih banyak siswa yang belum bisa menyelesaikan permasalahan dalam pelajaran matematika terutama pada materi Aritmatika Sosial. Pengalaman penulis dalam mengajarkan beberapa orang siswa, siswa tersebut juga mengalami kecemasan terhadap materi Aritmatika Sosial, karena membutuhkan pengetahuan materi aljabar. Berdasarkan wawancara yang penulis lakukan terhadap siswa-siswi MTsN Rukoh Banda Aceh, mereka mengatakan bahwa mereka belum begitu memahami apa yang telah dipelajari dan mereka merasakan kesulitan dalam meneyelesaikan soal, karena soal Aritmatika Sosial yang berbentuk cerita. Kemudian hasil wawancara dengan guru kelas VII mengatakan bahwa siswa masih kurang memahami cara menyelesaikan soal aritmatika sosial, dikarenakan siswa masih belum bisa megubah soal matematika kedalam model (simbol) matematika. Ini artinya, masih banyak siswa yang tidak memahami bagaimana menyelesaikan soal aritmatika sosial dengan baik. Selain itu juga banyak siswa yang merasa cemas dalam pembelajaran aritmatika sosial. Hal ini merupakan salah satu penyebab siswa tidak dapat mengikuti pembelajaran dengan tenang sehingga hasilnya siswa tidak memahami materi yang diajarkan. 
Salah satu cara yang dapat dilakukan agar pembelajaran tidak terasa sulit dan lebih menarik sehingga siswa tidak cemas dalam proses pembelajaran untuk meningkatkan pemahaman siswa pada materi Aritmatika Sosial adalah dengan menggunakan model pembelajaran Kooperatif tipe Rotating Trio Exchange (RTE). Rotating Trio Exchange merupakan cara mendalam peserta didik untuk berdiskusi tentang berbagai masalah dengan beberapa teman kelasnya, pertukaran itu dapat dengan mudah dilengkapi dengan materi pembelajaran. Pembelajaran kooperatif tipe RTE mengkondisikan siswa dalam satu kelas dibagi dalam kelompok, untuk mengerjakan tugas secara terstruktur yang diberikan oleh guru.

Ciri utama model pembelajaran Kooperatif tipe RTE adalah langkah Rotating (berputar kelompok), Trio (kelompok terdiri tiga anggota), Exchange (pergantian anggota kelompok). Pada pembelajaran Rotating Trio Exchange, pembelajaran disusun sedemikian sehingga masing-masing anggota dalam satu kelompok melaksanakan tanggung jawab pribadinya. Usaha setiap siswa akan dihargai dari setiap proses pembelajaran yang akan, sedang, dan telah berlangsung, karena itulah strategi $R T E$ ini sangat penting digunakan dalam proses pembelajaran.

Berdasarkan uraian diatas peneliti tertarik untuk mengangkat masalah ini menjadi suatu penelitian dengan judul "Penerapan model Pembelajaran Kooperatif tipe Rotating Tri Exchange (RTE) untuk mengurangi kecemasan matematika siswa."

Berdasarkan permasalahan uaraian di atas, maka permasalahan yang dapat diidentifikasikan adalah sebagai berikut: 1) Apakah penerapan model pembelajaran Kooperatif tipe RTE dapat mengurangi tingkat kecemasan matematika siswa? 2) Apakah tingkat kecemasan matematika siswa yang diajarkan melalui penerapan model pembelajaran Kooperatif tipe RTE lebih rendah dari tingkat kecemasan matematika siswa yang diajarkan melalui pembelajaran konvensional?

Berdasarkan rumusan masalah di atas, maka tujuan penelitian ini adalah: 1) Untuk mengetahui kecemasan matematika siswa setelah diterapkan model pembelajaran Kooperatif tipe Rotating Trio Exchange (RTE). 2) Untuk mengetahui tingkat kecemasan matematika siswa melalui penerapan model Rotating Trio Exchange (RTE) dengan pembelajaran konvensional.

\section{METODE PENELITIAN}

Pada penelitian ini, peneliti menggunakan pendekatan Kuantitatif, sedangkan desain penelitian adalah kuasi eksperimen kelompok kontrol tak setara (non equivalent control group desain).

Dalam penelitian ini, populasi penelitian adalah seluruh siswa kelas VII MTsN Rukoh Banda Aceh yang terdiri dari lima kelas. Subjek penelitian ini adalah siswa kelas VII-4 yang terdiri 31 orang dan kelas VII-2 yang terdiri dari 29 orang. Data dikumpulkan melalui pengukuran angket kecemasan matematika

Adapun teknik yang digunakan untuk mengumpulkan data dalam penelitian ini adalah angket kecemasan matematikas siswa dan observasi.

\section{Analisis Data Kecemasan Matematika Siswa}

Analisis data yang digunakan dalam penelitian ini dalah analisis data kuantitaif. Setelah data respon siswa terkumpul, perlu dilakukan analisis dengan cara menghitung nilai rata-rata keseluruhan skor masing-masing siswa yang telah dibuat dengan Skala Likert. Penskoran dalam kategori Skala Likert adalah untuk pertanyaan bersifat positif dengan 1, 2, 3, 4, dan 5 untuk pertanyaan negatif dengan niali 1, 2, 3, 4, dan 5. Skala Likert pada penelitian ini dipaparkan sebagai berikut.Untuk pertanyaan negatif, yaitu:

a. Skor 5 untuk Sangat Setuju

b. Skor 4 untuk Setuju 
c. Skor 3 untuk Tidak tahu

d. Skor 2 untuk tidak setuju

e. Skor 1 untuk Sangat tidak setuju

Sedangkan untuk pertanyaan positif diberikan skor sebaliknya, yaitu:

a. Skor 1 untuk sangat setuju

b. Skor 2 untuk setuju

c. Skor 3 tidak tahu

d. Skor 4 untuk tidak setuju

e. Skor 5 untuk sangat tidak setuju

Seorang siswa dikatakan cemas secara individual apabila skor yang diperoleh $2<$ skor ratarata $\leq 5$. Sedangkan siswa dikatakan tidak cemas secara individual apabila skor yang diperoleh $0<$ skor rata-rata $\leq 2$. Kriteria skor rata-rata kecemasan matematika untuk setiap siswa adalah sebagai berikut:

$4<$ skor rata-rata kecemasan $\leq 5=$ sangat cemas

$3<$ skor rata-rata kecemasan $\leq 4=$ cemas

$2<$ skor rata-rata kecemasan $\leq 3=$ Kecemasan sedang

$1<$ skor rata-rata kecemasan $\leq 2=$ tidak cemas

\section{HASIL PENELITIAN DAN PEMBAHASAN}

\section{Kecemasan Matematika Siswa}

Tabel 1. Perbandingan Jumlah Tingkat Kecemasan MatematikaSiswa sebelum dan setelah Penerapan RTE

\begin{tabular}{|c|c|c|}
\hline $\begin{array}{c}\text { Tingkat Kecemasan } \\
\text { Matematika }\end{array}$ & $\begin{array}{c}\text { Jumlah siswa sebelum } \\
\text { penerapan RTE }\end{array}$ & $\begin{array}{c}\text { Jumlah Siswa setelah } \\
\text { penerapan RTE }\end{array}$ \\
\hline Sangat Cemas & 2 & 0 \\
\hline Cemas & 15 & 4 \\
\hline Kecemasan Sedang & 8 & 16 \\
\hline Tidak Cemas & 6 & 11 \\
\hline Sangat Tidak Cemas & 0 & 0 \\
\hline
\end{tabular}

Dari tabel 1 dapat disimpulkan bahwa jumlah tingkat kecemasan matematika siswa sebelum dan setelah penerapan model kooperatif tipe RTE mengalami penurunan. Sebelum penerapan RTE jumlah siswa yang mengalami sangat cemas 2 orang dan setelah penerapan RTE siswa yang mengalami sangat cemas tidak ada lagi. Siswa yang mengalami cemas sebelum penerapan RTE 15 orang dan setelah penerapan RTE menjadi 4 orang. Siswa yang mengalami kecemasan sedang sebelum penerapan RTE 8 Orang setelah penerapan RTE menjadi 16 orang. Siswa yang tidak cemas sebalum penerapan RTE 6 orang dan setelah penerapan RTE menjadi 11 orang.

Data kecemasan siswa merupakan data berskala ordinal. Dalam prosedur statistik seperti ujian-t dan lain sebagainya, mengharuskan data berskala interval. Oleh sebab itu, sebelum digunakan uji-t, data ordinal perlu konversi ke data interval dalam penelitian ini menggunakan Metode Suksesif Interval (MSI). 
Tabel 2. Hasil Mengubah Data Angket Kecemasan Matematika Skala Ordinal Menjadi Skala Interval Menggunakan MSI Kelas Eksperimen (sebelum penerapan model RTE)

\begin{tabular}{|c|c|c|c|c|c|c|c|}
\hline Col & Category & Freq & Prop & Cum & Density & Z & Scale \\
\hline 1 & 1 & 59 & 0,126882 & 0,126882 & 0,20801 & $-1,14126$ & 1 \\
\hline & 2 & 151 & 0,324731 & 0,451613 & 0,396004 & $-0,12159$ & 2,060474 \\
\hline & 3 & 50 & 0,107527 & 0,55914 & 0,394551 & 0,148789 & 2,652916 \\
\hline & 4 & 190 & 0,408602 & 0,967742 & 0,072252 & 1,848596 & 3,428181 \\
\hline & 5 & 15 & 0,032258 & 1 & 0 & & 4,879216 \\
\hline
\end{tabular}

Tabel 3. Hasil Mengubah Data Angket Kecemasan Matematika Skala Ordinal Menjadi Skala Interval Menggunakan MSI Kelas Eksperimen (setelah penerapan model RTE)

\begin{tabular}{|r|r|r|l|r|r|r|r|}
\hline Col & $\begin{array}{l}\text { Categor } \\
\text { y }\end{array}$ & \multicolumn{1}{l|}{ Freq } & Prop & Cum & Density & Z & \multicolumn{2}{l|}{ Scale } \\
\hline 1 & 1 & 92 & 0,197002 & 0,197002 & 0,277423 & $-0,85238$ & 1 \\
\hline & 2 & 214 & 0,458244 & 0,655246 & 0,36834 & 0,399524 & 2,209818 \\
\hline & 3 & 59 & 0,126338 & 0,781585 & 0,294866 & 0,777556 & 2,989792 \\
\hline & 4 & 96 & 0,205567 & 0,987152 & 0,033136 & 2,230777 & 3,681426 \\
\hline & 5 & 6 & 0,012848 & 1 & 0 & & 4,987344 \\
\hline
\end{tabular}

Tabel 4. Data Interval Kecemasan Matematika Siswa Sebelum dan Setelah Menggunakan model RTE kelas eksperimen

\begin{tabular}{|c|c|c|c|c|}
\hline $\begin{array}{c}\text { Kode } \\
\text { Siwa }\end{array}$ & $\begin{array}{c}\text { Skor Rata- } \\
\text { rata/ siswa } \\
\text { sebelum RTE }\end{array}$ & Keterangan & $\begin{array}{c}\text { Skor Rata-rata/ } \\
\text { siswa setelah } \\
\text { RTE }\end{array}$ & Keterangan \\
\hline AF & 3 & Cemas & 3 & Cemas \\
\hline DRM & 3,3 & Cemas & 3,6 & Cemas \\
\hline DR & 2,5 & Kecemasan Sedang & 2,5 & KecemasanSedang \\
\hline DDS & 3,2 & Cemas & 3,4 & Cemas \\
\hline FI & 2,6 & Kecemasan Sedang & 2,3 & Kecemasan sedang \\
\hline FR & 2,8 & Cemas & 2,2 & Tidak Cemas \\
\hline F & 3,2 & Cemas & 2,5 & Kecemasan Sedang \\
\hline HAP & 3 & Cemas & 2,7 & Kecemasan Sedang \\
\hline HN & 2,6 & Kecemasan Sedang & 3,1 & Kecemasan Sedang \\
\hline KA & 1,9 & Tidak Cemas & 2 & Tidak Cemas \\
\hline KS & 2,1 & Kecemasan Sedang & 2,2 & Tidak Cemas \\
\hline MF & 2,8 & Cemas & 2,3 & Kecemasan Sedang \\
\hline MM & 3,1 & Cemas & 2,2 & Tidak Cemas \\
\hline NAV & 2,9 & Cemas & 2,6 & Kecemasan Sedang \\
\hline NCR & 2,9 & Cemas & 2,8 & Kecemasan Sedang \\
\hline NAM & 3,3 & Cemas & 2,9 & Kecemasan Sedang \\
\hline NH & 2 & Tidak Cemas & 1,8 & Tidak Cemas \\
\hline
\end{tabular}




\begin{tabular}{|c|c|c|c|c|} 
PS & 1,9 & Tidak Cemas & 1,1 & Tidak Cemas \\
\hline QA & 2,1 & Kecemasan Sedang & 1,9 & Tidak Cemas \\
\hline RAZ & 2,6 & Kecemasan Sedang & 1,6 & Tidak Cemas \\
\hline RN & 1,2 & Tidak Cemas & 1,3 & Tidak Cemas \\
\hline RZO & 2,7 & Cemas & 2,7 & Kecemasan Sedang \\
\hline SA & 2,9 & Cemas & 3,1 & Cemas \\
\hline SR & 1,9 & Tidak Cemas & 1,3 & Tidak Cemas \\
\hline TZZ & 2,2 & Kecemasan Sedang & 2,5 & Kecemasan Sedang \\
\hline UR & 3,5 & Sangat Cemas & 2,8 & Kecemasan Sedang \\
\hline WS & 3,3 & Cemas & 2,9 & Kecemasan Sedang \\
\hline ZR & 3,6 & Sangat Cemas & 2,6 & Kecemasan Sedang \\
\hline ZNA & 1,3 & Tidak Cemas & 1,1 & Tidak Cemas \\
\hline ZK & 3,1 & Cemas & 2,7 & Kecemasan Sedang \\
\hline ZM & 2,3 & Kecemasan Sedang & 2,5 & Kecemasan Sedang \\
\hline
\end{tabular}

Untuk melihat persentase kecemasan matematika siswa secara keseluruhan dapat digunakan rumus sebagai berikut:

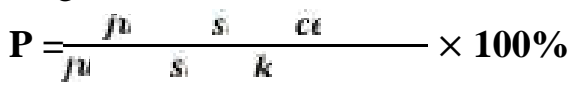

Berdasarkan kriteria rata-rata skor kecemasan matematika siswa, Sebelum penerapan model RTE tingkat kecemasan matematika siswa sebanyak $80,65 \%$ dan setelah pembelajaran menggunakan model RTE tingkat kecemasan matematika siswa menurun menjadi $64,51 \%$. Artinya pembelajaran dengan model RTE dapat mengurangi tingkat kecemasan matematika dari $80,65 \%$ menjadi $64,51 \%$. Berarti kecemasan matematika siswa berkurang sebanyak $16,14 \%$.

Tabel 5. Hasil Mengubah Data Angket Kecemasan Matematika Skala Ordinal Menjadi Skala Interval Menggunakan MSI Kelas Kontrol

\begin{tabular}{|c|c|c|c|c|c|c|c|}
\hline Col & Category & Freq & Prop & Cum & Density & Z & Scale \\
\hline 1 & 1 & 252 & 0,541935 & 0,541935 & 0,396736 & 0,105311 & 1 \\
\hline & 2 & 117 & 0,251613 & 0,793548 & 0,285318 & 0,818795 & 2,174889 \\
\hline & 3 & 36 & 0,077419 & 0,870968 & 0,210453 & 1,130978 & 2,699079 \\
\hline & 4 & 56 & 0,12043 & 0,991398 & 0,023362 & 2,382312 & 3,285595 \\
\hline & 5 & 4 & 0,008602 & 1 & 0 & & 4,447905 \\
\hline
\end{tabular}

Tabel 5. Data Interval Kecemasan Matematika Siswa Setelah Menggunakan Pembelajaran konvensional

\begin{tabular}{|c|c|c|c|c|}
\hline No & Kode Siswa & $\begin{array}{c}\text { Total } \\
\text { Skor }\end{array}$ & SkorRata-rara/Siswa & Keterangan \\
\hline 1 & AP & 54 & 3,6 & Cemas \\
\hline 2 & AA & 45 & 3 & Cemas \\
\hline 3 & AF & 51 & 3,4 & Sangat Cemas \\
\hline 4 & AQ & 37 & 2,46 & Kecemasan Sedang \\
\hline 5 & ARF & 33 & 2,2 & Kecemasan Sedang \\
\hline
\end{tabular}




\begin{tabular}{|c|c|c|c|c|}
\hline 6 & CANA & 34 & 2,26 & Kecemasan Sedang \\
\hline 7 & $\mathrm{DP}$ & 37 & 2,46 & Kecemasan Sedang \\
\hline 8 & FQM & 40 & 2,66 & Kecemasan Sedang \\
\hline 9 & $\mathrm{~F}$ & 30 & 2 & Kecemasan Sedang \\
\hline 10 & HA & 46 & 3,06 & Cemas \\
\hline 11 & MRDG & 33 & 2,2 & Kecemasan Sedang \\
\hline 12 & M & 35 & 2,33 & Kecemasan Sedang \\
\hline 13 & MAS & 39 & 2,6 & Kecemasan Sedang \\
\hline 14 & MM & 33 & 2,2 & Kecemasan Sedang \\
\hline 15 & MA & 42 & 2,8 & Kecemasan Sedang \\
\hline 16 & MAM & 27 & 1,8 & Tidak Cemas \\
\hline 17 & MD & 44 & 2,93 & Cemas \\
\hline 18 & MB & 17 & 1,13 & Tidak Cemas \\
\hline 19 & $\mathrm{RN}$ & 28 & 1,86 & Tidak Cemas \\
\hline 20 & RS & 24 & 1,6 & Tidak Cemas \\
\hline 21 & RZF & 40 & 2,66 & Kecemasan Sedang \\
\hline 22 & $\mathrm{RF}$ & 20 & 1,33 & Tidak Cemas \\
\hline 23 & RM & 47 & 3,13 & Cemas \\
\hline 24 & SR & 37 & 2,46 & Kecemasan Sedang \\
\hline 25 & TAP & 19 & 1,26 & Tidak Cemas \\
\hline 26 & TMU & 44 & 2,93 & Kecemasan Sedang \\
\hline 27 & $\mathrm{UI}$ & 18 & 1,2 & Tidak Cemas \\
\hline 28 & WA & 39 & 2,6 & Kecemasan Sedang \\
\hline 29 & $\mathrm{ZI}$ & 42 & 2,8 & Kecemasan Sedang \\
\hline
\end{tabular}

Rumusan hipotesis yang akan diuji dengan menggunakan uji-t adalah sebagai berikut:

$H_{a}: \mu_{2}=\mu_{1}:$ Tingkat kecemasan Matematika siswa melalui penerapan model RTE sama dengan tingkat kecemasan matematika siswa melalui pembelajaran konvensional

$H_{a}: \mu_{2}<\mu_{1}$ : Tingkat kecemasan Matematika siswa melalui penerapan model RTE lebih rendah dari tingkat kecemasan matematika siswa melalui pembelajaran konvensional

Uji yang digunakan adalah uji pihak kiri, pada taraf nyata $\alpha=0,05$. Kriteria pengujian di dapat dari daftar distribusi students $\mathrm{t} d \mathrm{k}=(\mathrm{n}-1)$ dan peluang $(1-\alpha)$. Jadi kita tolak $H_{\mathrm{U}}$ jika $\mathrm{t} \leq t_{1}-$ $\alpha$ dan terima $H_{a}$ dalam hal lainnya.

Nilai $t_{\text {hitung }}=0,283$ dan nilai $\boldsymbol{t}_{\text {tabe }}=1,68$. Berdasarkan kriteria pengujian adalah tolak $H_{a}$ jika $t_{\text {hitung }} \leq t_{\text {tabel }}$, telah didapat bahwa $t_{\text {hitung }}=0,283$ dan $t_{\text {tabel }}=1,68$. Ini artinya $t_{\text {hitung }}<t_{\text {tabel }}$ yaitu $0,283<$ 1,68 sehingga $H_{a}$ ditolak, maka $H_{a}$ diterima. Sehingga, dapat disimpulkan bahwa tingkat kecemasan matematika siswa melalui penerapan model RTE lebih rendah dari tingkat kecemasan matematika siswa melalui pembelajaran konvensional.

Selanjutnya, dikatakan tingkat kecemasan matematika siswa berkurang apabila kriteria "sangat cemas, cemas dan kecemasan sedang" menurun kedalam kriteria "tidak cemas dan bahkan tidak cemas". Setelah skor rata-rata angket pengukuran kecemasan masing-masing siswa diperoleh 
rata-ratanya, didapatkan bahwa sebelum menggunakan model RTE terdapat 25 siswa tergolong ke dalam cemas yang tingkatnya berbeda dan setelah penerapan model RTE tingkat kecemasan matematika siswa menurun dalam cemas yang tingkatannya berbeda-beda pula. Bahkan jumlah siswa yang cemas menurun dari 25 siswa menjadi 20 siswa. Melalui penerapan model RTE, peneliti mendesain Lembar Kerja Siswa (LKS) yang berisi masalah-masalah kehidupan nyata mengenai Aritmatika Sosial sehingga siswa lebih tertarik dalam menyelesaikan masalah tersebut.

\section{KESIMPULAN}

Berdasarkan tujuan dan hasil analisis data, maka diperoleh kesimpulan dalam penelitian ini adalah sebagai berikut: 1) Sebelum penerapan model RTE jumlah siswa yang mengalami sangat cemas 2 orang dan setelah penerapan siswa yang mengalami sangat cemas tidak ada lagi. Siswa yang mengalami cemas sebelum penerapan 15 orang dan setelah penerapan menjadi 4 orang. Siswa yang mengalami kecemasan sedang sebelum penerapan 8 0rang setelah penerapan menjadi 16 orang. Siswa yang tidak cemas sebelum penerapan 6 orang dan setelah penerapan menjadi 11 orang. Pesentase kecemasan siswa secara keleuruha, Sebelum penerapan model RTE tingkat kecemasan matematika siswa sebanyak $80,65 \%$ dan setelah pembelajaran menggunakan model RTE tingkat kecemasan matematika siswa menurun menjadi $64,51 \%$. Artinya pembelajaran dengan model RTE dapat mengurangi tingkat kecemasan matematika dari $80,65 \%$ menjadi $64,51 \%$. Berarti kecemasan matematika siswa berkurang sebanyak $16,14 \%$. 2) Dari hasil penelitian digunakanlah statistik uji-t pihak kiri dengan taraf signifikan $5 \%$. Berdasarkan kriteria pengujian adalah tolak $H_{a}$ jika $t_{\text {hitung }} \leq t_{\text {tabel }}$, telah didapat bahwa $t_{\text {hitung }}=0,283$ dan $t_{\text {tabel }}=1,68$. Ini artinya $t_{\text {hitung }}<t_{\text {tabel }}$ yaitu $0,283<1,68$ sehingga $H_{a}$ ditolak, maka $H_{a}$ diterima. Sehingga, dapat disimpulkan bahwa tingkat kecemasan matematika siswa melalui penerapan model RTE lebih rendah dari tingkat kecemasan matematika siswa melalui pembelajaran konvensional.

\section{REFERENCES}

Ahmad Dzulfikar. Studi Literatur: Pembelajaran Kooperatif dalam Mengatsi Kecemasan Matematika dan Mengembangkan Self Efficacy Matematis Siswa, seminar nasional matematika FMIPA UNY. 9 november 2013.

Budiyono, Matematika Berperan dalam pengembangan Iptek, Serambi Indonesia Mulyono Abdurrahman, (2009). Pendidikan Bagi Anak Berkesulitan Belajar, Jakarta: Rineka Cipta.

Sadia. I W, Model Pembelajaran yang Efektif untuk Meningkatkan Keterampilan Berpikir Kritis, Jurnal Pendidikan dan Pengajaran Undiksha, 41(2), 219-237, 2008.

Silberman. M,(2009). Active Learning 101 Strategi Pembelajaran Aktif, Jakarta: Insan Madani.

Soraya Alwarizma, Meningkatkan Aktivitas dan Hasil Belajar Siswa dengan Metode Latihan, Jurnal Inovatif Pendidikan Sain, vol.5, No2, Oktober, (diakses 11 Januari 2017)

Sudjana, (2002), Metode Statistika, Bandung: Tarsito Mukhlis

Sukardi, (2004), Metodelogi Penelitian Pendidikan. Jakarta: Bumi Aksara 